\title{
Application of different sources and doses of boron in the corn crop
}

\author{
Angela Oliveira Silva1, Wilian Henrique Diniz Buso ${ }^{1}$ \\ ${ }^{1}$ Instituto Federal Goiano, Campus Ceres, Ceres, Goiás, Brasil. E-mail: angela--oliveira@ hotmail.com, wilian.buso@ifgoiano.edu.br
}

Received: 04/03/2020; Accepted: 01/07/2020.

\begin{abstract}
One of the main problems faced in corn cultivation, especially in Cerrado regions, is the deficiency of micronutrients. Among the micronutrients essential for the development of plants, boron (B) stands out for participating in a series of physiological processes. Based on this, the present work aimed to evaluate the performance of corn under fertilization with different sources and doses of boron. The randomized block design in a $4 \times 3$ factorial scheme was used. Four boron doses $\left(0,1,2\right.$, and $\left.3 \mathrm{~kg} \mathrm{ha}^{-1}\right)$ and three nutrient sources (boric acid, borax, and ulexite), applied in topdressing, were evaluated. Plant height $(\mathrm{cm})$, stem diameter (mm), first ear insertion height $(\mathrm{m})$, ear length $(\mathrm{cm})$, ear diameter $(\mathrm{mm})$, number of rows per ear, number of grains per row, 1000grain weight $(\mathrm{g})$, and grain yield $\left(\mathrm{kg} \mathrm{ha}^{-1}\right)$ were evaluated. It was concluded that the boron sources and doses used did not influence the results of plant height, first ear insertion height, number of rows per ear, and grain yield. The three doses evaluated provided increases in stem diameter, with a dose of $2.08 \mathrm{~kg} \mathrm{ha}^{-1}$ being the one with the highest average. The application of borax and ulexite results in higher values of ear diameter, number of grains per row, and 1000-grain weight. The dose of $1.74 \mathrm{~kg} \mathrm{ha}^{-1}$ of boron provides the highest 1000-grain weight.
\end{abstract}

Keywords: Zea mays L., mineral nutrition, micronutrient, boron fertilization.

\section{Aplicação de diferentes fontes e doses de boro na cultura do milho}

\section{RESUMO}

Um dos principais problemas enfrentados na cultura do milho, especialmente em regiões de Cerrado, é a deficiência de micronutrientes. Entre os micronutrientes essenciais para o desenvolvimento das plantas, o boro (B) destaca-se por participar de uma série de processos fisiológicos. Com base nisso, o presente trabalho objetivou avaliar o desempenho do milho à adubação boratada com diferentes fontes e doses de $\mathrm{B}$. O delineamento experimental foi de blocos ao acaso, em arranjo fatorial $4 \times 3$, com quatro doses de $\mathrm{B}\left(0,1,2\right.$ e $\left.3 \mathrm{~kg} \mathrm{ha}^{-1}\right)$ e três fontes nutrientes (ácido bórico, bórax e ulexita), aplicadas em cobertura. As variáveis avaliadas foram altura de plantas (cm), diâmetro do colmo ( $\mathrm{mm})$, altura de inserção da primeira espiga $(\mathrm{m})$, comprimento de espiga (cm), diâmetro de espiga (mm), número de fileiras por espiga, número de grãos por fileira, massa de mil grãos $(\mathrm{g})$ e produtividade $\left(\mathrm{kg} \mathrm{ha}^{-1}\right)$. Concluiu-se que as fontes e doses de B utilizadas não apresentaram diferenças estatísticas entre si nos resultados de altura de plantas, altura de inserção da primeira espiga, número de fileiras por espiga e produtividade. As três doses avaliadas proporcionaram acréscimos no diâmetro do colmo, sendo a dose de $2,08 \mathrm{~kg}^{-1} \mathrm{a}^{-1}$ que obteve a melhor média. A aplicação de bórax e ulexita resulta em maior diâmetro da espiga, número de grãos por fileira e massa de mil grãos. A dose de $1,74 \mathrm{~kg} \mathrm{ha}^{-1}$ de B proporciona maior massa de mil grãos.

Palavras-chave: Zea mays L., nutrição mineral, micronutriente, adubação boratada. 


\section{Introduction}

Corn (Zea mays L.) is one of the main agricultural commodities, it is used mainly for animal feeding, and its demand in the market grows every year (CONAB, 2018). Brazil stands out as the 3rd largest world producer of this grain, with an estimated production of more than 99 million tons in the 2018/2019 harvest. The State of Goiás is the 5th largest national producer, and the 2 nd in the Midwest region (CONAB, 2019).

The search for technologies that solve problems related to pests, diseases, nutritional deficiencies, and climatic factors is constant to reach such high levels of grain yield (Tavares et al., 2015). One of the problems faced by corn producers is the deficiency of micronutrients, caused mainly by cultivation in low fertility soils - such as those in the Cerrado, by exporting nutrients with the harvest and by applying high doses of limestone (Nogueira et al., 2019). Boron (B) deficiency is one of the most common among micronutrients, occurring more frequently in sandy soils through the leaching of the nutrient into layers not reached by plant roots.

Boron is directly related to several plant physiological processes, such as cell wall synthesis and structuring, sugar transport, carbohydrate metabolism, pollen grains germination, among other important processes. Besides, it also acts indirectly in the activation of enzymes and translocation of nucleic acids, carbohydrates, and phytohormones (Songkhum et al., 2018; Nogueira et al., 2019).

Despite the importance of this nutrient, few studies address the ideal management of boron fertilization in corn. Thus, this study aimed to evaluate the performance of corn under fertilization with different doses and sources of boron in the Cerrado.

\section{Material and Methods}

The experiment was conducted from April 2019 to September 2019 in an experimental area with center pivot irrigation, in the Goiano Federal Institute - Campus of

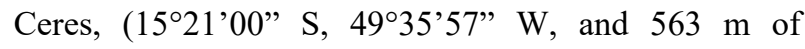
altitude). The climate of the region, according to the Köppen classification, is humid tropical (Aw-type), with dry winter and rainy summer.

Soil samples were collected at the $0-20 \mathrm{~cm}$ layer for physico-chemical analysis to assessing soil fertility, and the results are shown in Table 1 . A randomized block experimental design in a $4 \times 3$ factorial scheme with four replications was used. Four doses $\left(0,1,2\right.$, and $\left.3 \mathrm{~kg} \mathrm{ha}^{-1}\right)$ and three sources of boron (boric acid $-17.48 \%$, borax -
$11.3 \%$, and ulexite - 10\%) were applied as topdressing fertilization, on May 17, 2019, when the corn plants had four fully expanded leaves.

The soil tillage was carried out with a plowing, and a harrowing the day before sowing. The LG 3055 PRO $3^{\circledR}$ hybrid was used. The sowing was carried out on April 27, 2019, with a row spacing of $0.5 \mathrm{~m}$, and a seed drill. Each plot consisted of four rows $5 \mathrm{~m}$ long, with only the two central rows being used as a useful area, with $0.5 \mathrm{~m}$ at the ends as a border.

As fertilization, $16 \mathrm{~kg} \mathrm{ha}^{-1}$ of $\mathrm{N}, 120 \mathrm{~kg} \mathrm{ha}^{-1}$ of $\mathrm{P}_{2} \mathrm{O}_{5}$, and $40 \mathrm{~kg} \mathrm{ha}^{-1}$ of $\mathrm{K}_{2} \mathrm{O}$ were applied, using the NPK formulation 04:30:10. The topdressing fertilization was carried out 20 days after sowing, with the application of $135 \mathrm{~kg} \mathrm{ha}^{-1}$ of $\mathrm{N}$ using urea as a source.

Weed control was performed with the application of S-metolachlor $\left(1.25 \mathrm{~L} \mathrm{ha}^{-1}\right)$ in pre-emergence and glyphosate $\left(3 \mathrm{~L} \mathrm{ha}^{-1}\right)$ in post-emergence. The corn leafhopper (Dalbulus maydis) control was performed with the insecticides thiamethoxam (200 $\left.\mathrm{g} \mathrm{ha}^{-1}\right)$, chlorpyrifos (0.6 L ha' $\left.\mathrm{L}^{-1}\right)$ and pyriproxyfen $\left(0.3 \mathrm{~L} \mathrm{ha}^{-1}\right)$, even so, there was incidence of stunting on plants.

Five plants were chosen at random from each treatment and block, and the variables analyzed were: a) plant height: with a measuring tape, the height of the plants was measured, from their base to the tassel; the results were expressed in $\mathrm{m}$; b) stem diameter: determined using a digital caliper; the results were expressed in $\mathrm{mm}$; c) first ear insertion height: the height from the base of the plant to its first ear, measured with a measuring tape; the results were expressed in $m$; d) ear length: determined using a graduated ruler; the results were expressed in $\mathrm{cm}$; e) ear diameter: determined using a digital caliper; the results were expressed in $\mathrm{mm}$; $\mathrm{f}$ ) the number of rows per ear: obtained from the count of rows present in the ears sampled at random; g) the number of grains per row: determined from the count of the number of grains present in the rows of sampled ears; i) 1000grain weight: after threshing, on a digital scale, four samples of 1000 grains of the sampled ears were weighed, and, from that, the calculation was made to determine the 1000-grain weight; the results were expressed (g). The harvest took place on September 22, 2019 , all ears of the two central rows were threshed. The grain yield was corrected to $13 \%$ of moisture and estimated in $\mathrm{kg} \mathrm{ha}^{-1}$.

The data obtained in the experiment were subjected to analysis of variance, Tukey test at $5 \%$ significance for comparison of means, and regression analysis of variables according to the boron doses, with the aid of the statistical software R. 
Table 1. Particle-size and chemical characteristics of the soil in the $0-0.20 \mathrm{~m}$ layer, Ceres, GO, 2019.

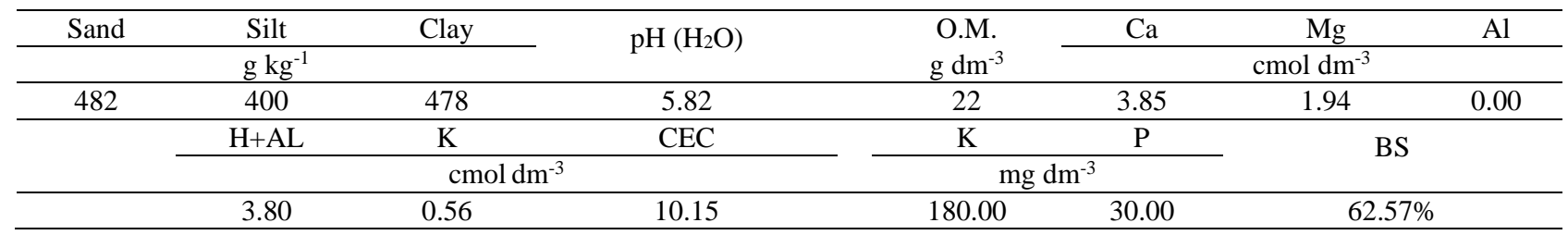

CEC: Cation exchange capacity; O.M.: Organic matter; BS: Base saturation.

Source: Soil analysis laboratory at IF Goiano Campus of Ceres, 2019.

\section{Results and Discussion}

The results of the analysis of variance of plant height, first ear insertion height, number of rows per ear, and grain yield were not significant, indicating that there were no statistical differences for the sources and doses used, as well as there was no significant interaction between sources and doses.

For the stem diameter, there was no significant interaction between sources and doses of boron, with a considerable difference only for the boron doses used. The means of stem diameter are shown in Table 2. All boron doses evaluated had mean stem diameter higher than the control $\left(0 \mathrm{~kg} \mathrm{ha}^{-1}\right.$ of boron).

The stem diameter is defined during the plant development, and boron is an essential element; it participates in the cell wall along with calcium, so when the boron source is applied in topdressing, those sources with higher solubility make this nutrient available faster than the sources with low water solubility. Studying the use of boron fertilization and wastewater in the cultivation of sunflower, Santos Junior et al. (2011) used five boron doses $\left(0,2,4,6\right.$, and $\left.8 \mathrm{~kg} \mathrm{ha}^{-1}\right)$, through the application of boric acid in the sowing furrow, they observed that these doses did not promote results statistically superior to those of the control in the variable stem diameter.

The doses showed significant results in the regression analysis, adjusting to the quadratic model, as shown in Figure 1. Thus, regardless of the boron source used, the dose that resulted in the largest stem diameter was 2.08 $\mathrm{kg} \mathrm{ha}^{-1}$ of boron.

As Ferreira (2012) reports, boron is an essential micronutrient for plant growth, as it is related to the stability of the cell wall and the growth of apical meristems. Based on this statement, it was expected that boron fertilization would promote higher increments in the stem diameter, which was not observed in the present study when using the ulexite.

Jamami et al. (2006), evaluating foliar fertilization in corn with three boron doses of $\mathrm{B}\left(0,1\right.$, and $\left.2 \mathrm{~kg} \mathrm{ha}^{-1}\right)$ and boric acid as a source, found that there was no significant difference between treatments in the stem diameter variable, which presented means between 19 and $21 \mathrm{~mm}$. Soomro et al. (2011), comparing ways of boron application in corn for forage, observed that the application of $2 \mathrm{~kg} \mathrm{ha}^{-1}$ of boron in the sowing furrow, using boric acid as a source. However, it was superior to the control $\left(0 \mathrm{~kg} \mathrm{ha}^{-1}\right.$ of boron $)$ in the stem diameter, showed results lower than those obtained by the foliar application of boron. These authors explain that the foliar application of this micronutrient is more advantageous because the plant absorbs it in the place where it will be used quickly. At the same time, in soil, boron can present problems due to its solubility and leaching due to the high mobility of this nutrient.

For the ear length, the results of the analysis of variance indicated the interaction between sources and doses of boron at $5 \%$ probability (Table 3 ). It is observed that, at a dose of $1 \mathrm{~kg} \mathrm{ha}^{-1}$ of boron, the borax obtained the highest average ear length $(17.46 \mathrm{~cm})$. However, it was not statistically different from the ulexite, and both were superior to boric acid. At the doses of 2 and $3 \mathrm{~kg} \mathrm{ha}^{-}$ ${ }^{1}$ of boron, there was no significant difference between the three sources.

Table 2. Stem diameter $(\mathrm{mm})$ of corn plants according to different boron doses. Ceres, 2019.

\begin{tabular}{cc}
\hline Boron doses $\left(\mathrm{kg} \mathrm{ha}^{-1}\right)$ & Stem diameter $(\mathrm{mm})$ \\
\hline 0 & $24.99 \mathrm{~b}$ \\
1 & $27.35 \mathrm{a}$ \\
2 & $27.23 \mathrm{a}$ \\
3 & $27.28 \mathrm{a}$ \\
\hline
\end{tabular}

$\overline{\mathrm{CV}}=$ Coefficient of variation.

Means followed by the same letter in the column do not differ by the Tukey test at $5 \%$ probability.

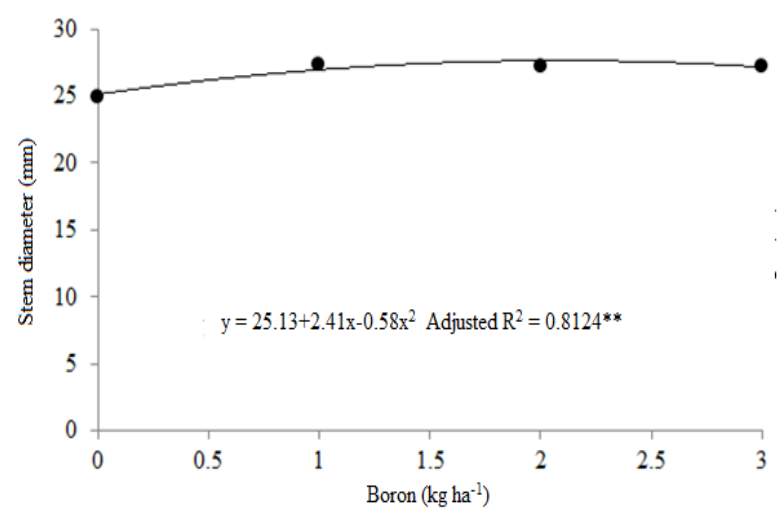

Figure 1. Stem diameter of corn plants according to different boron doses. Ceres, 2019. 
Table 3. Ear length (cm) of corn plants according to different doses and sources of boron. Ceres, 2019.

\begin{tabular}{ccccc}
\hline \multirow{2}{*}{ Source } & \multicolumn{4}{c}{ Boron doses $\left(\mathrm{kg} \mathrm{ha}^{-1}\right)$} \\
\cline { 2 - 5 } & 0 & 1 & 2 & 3 \\
\hline Boric acid & $15.60 \mathrm{bB}$ & $16.06 \mathrm{bB}$ & $16.96 \mathrm{aAB}$ & $17.72 \mathrm{aA}$ \\
Borax & $15.60 \mathrm{bB}$ & $17.46 \mathrm{aA}$ & $16.80 \mathrm{aAB}$ & $17.03 \mathrm{aAB}$ \\
Ulexite & $17.36 \mathrm{aA}$ & $17.36 \mathrm{abA}$ & $17.44 \mathrm{aA}$ & $17.08 \mathrm{aA}$ \\
\hline \multicolumn{5}{c}{$\mathrm{CV}=3.91 \%$} \\
\hline \multicolumn{5}{c}{} \\
\hline
\end{tabular}

$\mathrm{CV}=$ Coefficient of variation.

Means followed by the same lowercase letter in the column and uppercase letter in the lines do not differ by the Tukey test at $5 \%$ probability.

In the regression analysis, it was found that the boric acid data showed significant results, adjusting to the linear regression model. The data obtained by applying borax and ulexite did not fit the linear and quadratic regression models (Figure 2). The dose of $3 \mathrm{~kg} \mathrm{ha}^{-1}$ of boron resulted in a longer ear length.

According to Dourado Neto et al. (2004), the length of the ear can directly affect the number of grains per row and, consequently, grain yield. These authors, using four different doses of boron $\left(0,2,4\right.$, and $\left.8 \mathrm{~kg} \mathrm{ha}^{-1}\right)$ and boric acid as source applied in the sowing furrow, observed that boron doses did not promote significant results in the ear length. In this study, the means of this variable ranged from 17.2 to $18.1 \mathrm{~cm}$.

The results of ear diameter, number of grains per row, and grain yield are shown in Table 4. There was no influence of the interaction between boron sources and doses on the ear diameter, number of grains per row, and 1000-grain weight. However, the results of the analysis of variance indicated significant differences between the boron sources used, with no adjustment to the models of linear and quadratic regression according to the boron doses, regardless of the source. There was no influence of the doses and sources of boron and the interaction between sources and doses on grain yield.

The average ear diameter ranged between 44.48 and $47.52 \mathrm{~mm}$, and the highest average ear diameter was observed with the application of ulexite, which did not differ statistically from the borax. The average grains per row ranged between 24.68 and 27.81, with the highest averages observed with borax and ulexite (Table 5). The results obtained in the present study for the ear diameter were close to those described by Jamami et al. (2006), who found means between 46 and $49 \mathrm{~mm}$. However, these authors used only boric acid as the source of the micronutrient and found no significant differences between the doses evaluated $\left(0,1\right.$, and $\left.2 \mathrm{~kg} \mathrm{ha}^{-1}\right)$.

Regarding the variable number of grains per row obtained in the present study, it was lower than those described by Dourado Neto et al. (2004), who found averages between 34.8 and 39.1. These authors found that the $8 \mathrm{~kg} \mathrm{ha}^{-1}$ dose of $\mathrm{B}$ was the only one that promoted significant effects on this variable.

Grain yield ranged between 3582.32 and $3787.17 \mathrm{~kg}$ $\mathrm{ha}^{-1}$. In studies about this topic, the effects of boron on crop productivity are controversial. Dourado Neto et al. (2004), studying doses from 0 to $8 \mathrm{~kg} \mathrm{ha}^{-1}$ of boron, found averages corn yield between 7499 and $8701.8 \mathrm{~kg} \mathrm{ha}^{-1}$, and the boron doses used did not influence grain yield. Jamami et al. (2006) also found no differences between the boron doses evaluated in their study $(0,1$, and $2 \mathrm{~kg}$ $\left.\mathrm{ha}^{-1}\right)$, and obtained average yield between 4318 and 4662 $\mathrm{kg} \mathrm{ha}^{-1}$.

Silva et al. (2014), in a study with boron fertilization in rice cultivation in Cerrado soil, used five different doses of the micronutrient $(0,0.5,1.0,1.5,2.0$, and 2.5 $\mathrm{kg} \mathrm{ha}^{-1}$ ), provided by boric acid, and found that the highest dose used provided increases in the grain yield of this crop. These authors also concluded that the response to boron fertilization is higher in soils with low organic matter content. Galindo et al. (2018), working with four boron doses $\left(0,1,2\right.$, and $\left.4 \mathrm{~kg} \mathrm{ha}^{-1}\right)$ and boric acid as a source in the wheat crop, found that the application of 2 $\mathrm{kg} \mathrm{ha}^{-1}$ of boron in the sowing furrow resulted in higher grain yield. Kappes et al. (2008), studying the effects of foliar fertilization with different boron doses $(0,0.1,0.2$, 0.3 , and $\left.0.4 \mathrm{~kg} \mathrm{ha}^{-1}\right)$, found no significant impact of the application of this micronutrient on grain yield of the soybean crop.

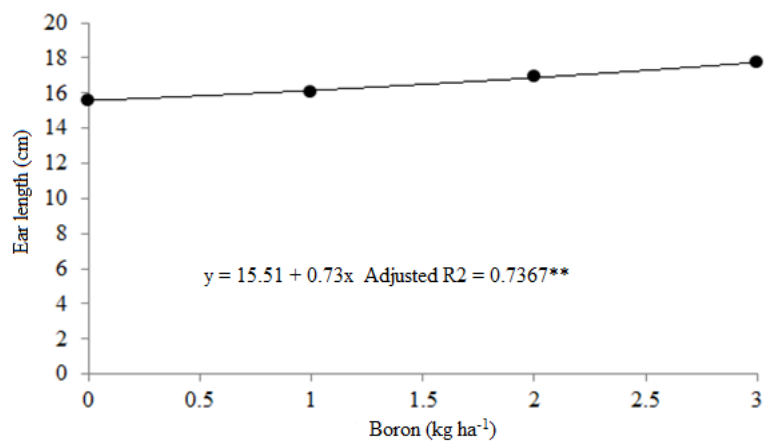

Figure 2. Ear length of corn plants according to different boron doses. Ceres, 2019. 
Table 4. Ear diameter, number of grains per row, 1000-grain weight, and grain yield of corn according to the different boron sources applied in topdressing fertilization. Ceres, 2019.

\begin{tabular}{ccccc}
\hline Source & Ear diameter $(\mathrm{mm})$ & Number of grains per row $\left(\mathrm{n}^{\circ}\right)$ & 1000-grain weight $(\mathrm{g})$ & Grain yield $\left(\mathrm{kg}\right.$ ha $\left.{ }^{-1}\right)$ \\
\hline Boric acid & $44.48 \mathrm{~b}$ & $24.68 \mathrm{~b}$ & $365.16 \mathrm{~b}$ & $3482.32 \mathrm{a}$ \\
Borax & $46.12 \mathrm{ab}$ & $27.81 \mathrm{a}$ & $374.39 \mathrm{a}$ & $3517.50 \mathrm{a}$ \\
Ulexite & $47.52 \mathrm{a}$ & $26.78 \mathrm{a}$ & $389.16 \mathrm{a}$ & $3787.17 \mathrm{a}$ \\
\hline $\mathrm{CV}=$ & $4.59 \%$ & $7.18 \%$ & $3.98 \%$ & $10.69 \%$ \\
\hline
\end{tabular}

$\mathrm{CV}=$ Coefficient of variation.

Means followed by the same letter in the column do not differ by the Tukey test at $5 \%$ probability.

Table 5. 1000-grain weight (g) of corn according to different boron doses. Ceres, 2019.

\begin{tabular}{cc}
\hline Boron doses $\left(\mathrm{kg} \mathrm{ha}^{-1}\right)$ & 1000-grain weight $(\mathrm{g})$ \\
\hline 0 & $339.84 \mathrm{c}$ \\
1 & $406.19 \mathrm{a}$ \\
2 & $388.91 \mathrm{ab}$ \\
3 & $376.66 \mathrm{~b}$ \\
\hline
\end{tabular}

$\mathrm{CV}=$ Coefficient of variation.

Means followed by the same letter in the column do not differ by the Tukey test at $5 \%$ probability.

1000-grain weight ranged between 365.16 and 389.16 $\mathrm{g}$ depending on the sources used, with borax and ulexite being those that resulted in the highest averages. In this variable, there was also a significant difference between the doses evaluated. The averages are shown in Table 5, where it is possible to notice that the dose of $1.0 \mathrm{~kg} \mathrm{ha}^{-1}$ of boron provided the largest 1000-grain weight; however, it was statistically equal to dose $2.0 \mathrm{~kg} \mathrm{ha}^{-1}$ of boron.

The regression analysis indicated a significant effect of the doses, whose data fitted better to the quadratic regression model, and the dose that resulted in the highest 1000 -grain weight was $1.74 \mathrm{~kg} \mathrm{ha}^{-1}$ of $\mathrm{B}$, as shown in Figure 3. Doses higher than this promote a decline in the 1000-grain weight, which can harm the crop yield.

The results obtained in the present study differ from those described by Kappes et al. (2008). They, working with the application of boron doses $(0,0.1,0.2,0.3$, and $0.4 \mathrm{~kg} \mathrm{ha}^{-1}$ ) via leaf, found no significant differences for the 1000-grain weight. In this study, the authors used a liquid fertilizer with $10 \%$ of boron concentration.

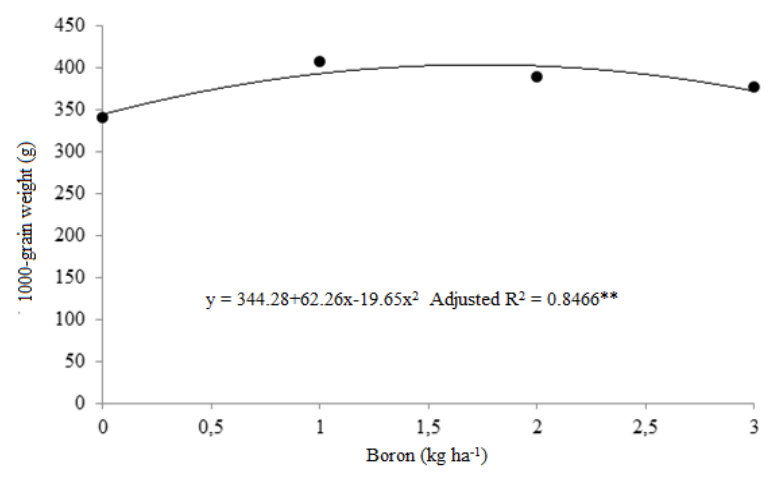

Figure 3. 1000-grain weight of corn according to different sources and doses of boron.
No studies were found using borax and ulexite as a source of boron for a better discussion of the results obtained.

\section{Conclusions}

The three doses evaluated promoted increases in the stem diameter of corn plants, and the dose of $2.08 \mathrm{~kg} \mathrm{ha}^{-}$

${ }^{1}$ of Boron provided the best result for this variable.

Boron fertilization using borax and ulexite resulted in a larger ear diameter, number of grains per row, and 1000-grain weight.

The boron dose of $1.74 \mathrm{~kg} \mathrm{ha}^{-1}$ provided the highest 1000-grain weight.

\section{Bibliographic References}

CONAB. Companhia Nacional de Abastecimento, 2019. Acompanhamento da safra brasileira de grãos. Volume 6 - Safra 2018/19 - Décimo segundo levantamento, setembro 2019. Brasília, CONAB, $121 \mathrm{p}$

CONAB. Companhia Nacional de Abastecimento, 2018. Perspectivas para a agropecuária. Volume 6 - Safra 2018/19. Brasília, CONAB, 112 p.

Dourado Neto, D., Favarin, J.L., Manfron, P.A., Pilau, F.G., Soares, M.A., Bonecarrère, R.A.G., Ohse, S., 2004. Efeito de boro e nitrogênio na cultura do milho. Insula, 33(1), 51-67.

Ferreira, M.M.M., 2012. Sintomas de deficiência de macro e micronutrientes de plantas de milho híbrido BRS 1010. Revista Agro@mbiente Online, 6(1), 74-83. DOI: http://dx.doi.org/10.18227/1982-8470ragro.v6i1.569.

Galindo, F.S., Teixeira Filho, M.C.M., Buzetti, S., Boleta, E.H.M., Rodrigues, W.L., Rosa, A.R.M., 2018. the application forms and doses of boron affect wheat crops? Revista Brasileira de Engenharia Agrícola e Ambiental, 22(9), 597-603. DOI: http://dx.doi.org/10.1590/1807-1929/agriambi.v22n9p597-603.

Jamami, N., Büll, L.T., Corrêa, J.C., Rodrigues, J.D., 2006. Resposta da cultura do milho (Zea mays L.) à aplicação de boro e zinco no solo. Acta Scientiarum Agronomy, 28(1), 99-105. DOI: doi.org/10.4025/actasciagron.v28i1.1683.

Kappes, C., Gollo, A.L., Carvalho, M.A.C., 2008. Doses e épocas de aplicação foliar de boro nas características agronômicas e na qualidade de sementes de soja. Scientia Agraria, 9(3), 291-297. DOI: dx.doi.org/10.5380/rsa.v9i3.11563. 
Nogueira, L.M., Teixeira Filho, M.C.M., Megda, M.M., Galindo, F.S., Buzetti, S., Alves, C.J., 2019. Corn nutrition and yield as a function of boron rates and zinc fertilization. Semina: Ciências Agrárias, 40(6), 2545-2560. DOI: dx.doi.org/10.5433/1679-0359.2019v40n6p2545.

Santos Junior, J.A., Gheyi, H.R., Dias, N.S., Soares, F.A.L., Nobre, R.G., 2011. Doses de boro e água residuária na produção de girassol. Revista Ciência Agronômica, 42(4), 857-864.

Silva, I.F., Barbosa, A.M., Tiritan, C.S., Catuchi, T.A., 2014. Adubação boratada na cultura do arroz em solos de Cerrado de baixa fertilidade. Colloquium Agrariae, 10(especial), 1-8. DOI: 10.5747/ca.2014.v10.nesp.000130.
Songkhum, P., Wuttikhun, T., Chanlek, N., Khemthong, P., Laohhasurayotin, K., 2018. Controlled release studies of boron and zinc from layered double hydroxides as the micronutrient hosts for agricultural application. Applied Clay Science, 152, 311-322. DOI: 10.1016/j.clay.2017.11.028.

Soomro, Z.H., Baloch, P.A., Gandhai, A.W., 2011. Comparative effects of foliar and soil applied boro non growth and fodder yield of maize. Pakistan Journal of Agricultural Sciences, 27(1), 18-26.

Tavares, L.C., Oliveira, S., Lemes, L.S., Meneghello, G.E., 2015. Qualidade fisiológica e crescimento inicial de sementes de milho recobertas com micronutrientes. Revista de Agricultura, 90(2), 156-167. 